\title{
High Nitrogen Removal in a Constructed Wetland Receiving Treated Wastewater in a Cold Climate
}

\section{Uusheimo, Sari Anneli}

$2018-11-20$

Uusheimo , S A , Huotari , J T , Tulonen , T V , Aalto , S L , Rissanen , A J \& Arvola , L M J 2018 , ' High Nitrogen Removal in a Constructed Wetland Receiving Treated Wastewater in a Cold Climate ' , Environmental Science \& Technology , vol. 52 , no. 22 , pp. 13343-13350 . https://doi.org/10.1021/

http://hdl.handle.net/10138/322303

https://doi.org/10.1021/acs.est.8b03032

acceptedVersion

Downloaded from Helda, University of Helsinki institutional repository.

This is an electronic reprint of the original article.

This reprint may differ from the original in pagination and typographic detail.

Please cite the original version. 
1 High nitrogen removal in a constructed wetland receiving treated wastewater in a cold climate

$2{ }^{*}$ Sari Uusheimo ${ }^{1}$, Jussi Huotari ${ }^{1}$, Tiina Tulonen ${ }^{1}$, Sanni L. Aalto ${ }^{2,3}$, Antti J. Rissanen ${ }^{4}$, Lauri Arvola ${ }^{1}$

$4{ }^{1}$ University of Helsinki, Faculty of Biological and Environmental Sciences,

5 Ecosystems and Environment Research Programme, Lammi Biological Station, Pääjärventie 320, FI-

616900

$7 \quad{ }^{2}$ University of Jyväskylä, Dept. of Biological and Environmental Sciences, P. O. Box 35, FI-40014

$8{ }^{3}$ University of Eastern Finland, Dept. of Environmental and Biological Sciences, P.O. Box 1627, FI-

$9 \quad 70211$

$10{ }^{4}$ Tampere University of Technology, Laboratory of Chemistry and Bioengineering, P. O. Box 541, FI-

1133101

12 ABSTRACT

13 Constructed wetlands provide cost-efficient nutrient removal, with minimal input of human labor and 14 energy, and their number is globally increasing. However, in northern latitudes, wetlands are rarely

15 utilized, because their nutrient removal efficiency has been questioned due to the cold climate. Here,

16 we studied nutrient retention and nitrogen removal in a boreal constructed wetland (4ha) receiving

17 treated nitrogen-rich wastewater. On a yearly basis, most of the inorganic nutrients were retained by the

18 wetland. The highest retention efficiency was found during the ice-free period, being $79 \%$ for ammonium-nitrogen $\left(\mathrm{NH}_{4}{ }^{+}-\mathrm{N}\right), 71 \%$ for nitrate-nitrogen $\left(\mathrm{NO}_{3}{ }^{-}-\mathrm{N}\right)$ and $88 \%$ for phosphate-phosphorus

$20\left(\mathrm{PO}_{4}{ }^{3-}-\mathrm{P}\right)$. Wetland also acted as a buffer zone during disturbed nitrification process of the wastewater 21 treatment plant. Denitrification varied between 106 and $252 \mathrm{mg} \mathrm{N} \mathrm{m}^{-2} \mathrm{~d}^{-1}$ during ice-free period.

22 During ice-cover period, total gaseous nitrogen removal was $147 \mathrm{mg} \mathrm{N} \mathrm{m}^{-2} \mathrm{~d}^{-1}$, from which $66 \%$ was

23 removed as $\mathrm{N}_{2}, 28.5 \%$ as nitrous oxide $\left(\mathrm{N}_{2} \mathrm{O}\right)$ through denitrification, and $5.5 \%$ as $\mathrm{N}_{2}$ through 
24 anammox. Nearly $2600 \mathrm{~kg} \mathrm{~N} \mathrm{y}^{-1}$ was estimated to be removed through microbial gaseous N-production

25 which equaled $72 \%$ of $\mathrm{NO}_{3}{ }^{-}-\mathrm{N}$ and $60 \%$ of $\mathrm{TN}$ yearly retention in the wetland. Wetland retained

26 nutrients even in winter, when good oxygen conditions prevailed under ice. The results suggest that

27 constructed wetlands are an efficient option for wastewater nitrogen removal and nutrient retention also 28 in cold climates.

INTRODUCTION

30 Since the 1960s, growing human population has substantially increased excess nitrogen $(\mathrm{N})$ in the 31 environment causing health, environmental and economic problems through e.g. aerosols and ground32 level ozone, loss of biodiversity, eutrophication and climate change. ${ }^{1}$ Although a major part of anthropogenic nutrient loading comes from non-point sources, point sources (e.g. wastewater effluents) can cause significant environmental problems, especially in small water bodies. ${ }^{2}$ In Finland, wastewater treatment plants (WWTPs) retain $>90 \%$ of the incoming phosphorus $(\mathrm{P})$, while $\mathrm{N}$ removal efficiency is generally lower, varying between $8-92 \% .^{3}$ Most modern WWTPs rely only on primary and secondary treatments ${ }^{4}$, and treated wastewater still contains high amounts of nitrate-nitrogen $\left(\mathrm{NO}_{3}{ }^{-}-\mathrm{N}\right)$ when entering the recipient water bodies.

Traditionally, $\mathrm{P}$ is considered as the key limiting nutrient for phytoplankton growth in freshwater systems $^{5-6}$, and therefore lake management has mainly focused on P reduction. However, freshwater systems can also be N-limited ${ }^{7-11}$ and the limiting nutrient can vary seasonally and spatially. ${ }^{12-14}$ Furthermore coastal seas, e.g. The Baltic Sea, are generally N-limited. ${ }^{15}$ In Finland, natural N retention efficiency of the Baltic coast is low $(0-20 \%)^{16}$, so more effort should be made in inland nutrient removal. A huge potential for nutrient reduction exists in WWTPs in the Baltic Sea area ${ }^{17}$, and recent cost-efficiency modeling results from Finland including both agricultural and WWTP sources suggest that $\mathrm{N}$ load abatement measures should be targeted at WWTPs that have low $\mathrm{N}$ reduction level. ${ }^{18}$ 
47 Constructed wetlands (CWs) can be an efficient and low-cost option for wastewater nutrient removal ${ }^{19-}$

$48 \quad{ }^{21}$ and polishing treated wastewater ${ }^{22}$, especially in small communities and in areas without centralized 49 wastewater treatment. CWs require no chemical and energy inputs, so maintenance costs are lower as 50 compared with conventional WWTPs. ${ }^{20}$ Maintenance includes the removal of excess vegetation and 51 sediment. However, it is not always clear whether the CWs can successfully be applied in a cold 52 climate. ${ }^{23,24}$

54 In wetlands, the most important $\mathrm{N}$ removal process is microbial-driven denitrification, where $\mathrm{NO}_{3}{ }^{-}$is 55 reduced to nitrous oxide $\left(\mathrm{N}_{2} \mathrm{O}\right)$, and further to nitrogen gas $\left(\mathrm{N}_{2}\right)$ under anoxic conditions. ${ }^{25}$

56 Traditionally, denitrification rates have been considered to decline with declining temperature ${ }^{26}$, but 57 previous studies conducted in boreal lakes have reported active denitrification also during cold seasons. ${ }^{27-29}$ The relative production of the greenhouse gas $\mathrm{N}_{2} \mathrm{O}$ is highly variable depending on environmental conditions (e.g. temperature, oxygen concentration, carbon $(\mathrm{C})^{30-32}$ ) suggesting that the 60 share of $\mathrm{N}_{2} \mathrm{O}$ from denitrification could be substantial in seasonally variable boreal environments. 61 Another pathway contributing to $\mathrm{N}$ removal is anaerobic ammonium oxidation (anammox), which is 62 important in environments with low organic $\mathrm{C}^{33-34}$ as well as in wastewaters. ${ }^{35}$ Unlike heterotrophic 63 denitrification, anammox produces no $\mathrm{N}_{2} \mathrm{O}$, requires no external $\mathrm{C}$ source ${ }^{35}$, and may thus remove $\mathrm{N}$ 64 year around.

66 In this study, we measured nutrient retention in a constructed wetland for two years at Lammi WWTP, 67 southern Finland. Our study questions were: 1) how efficiently does the wetland retain nutrients from treated wastewater? 2) does the retention efficiency vary between seasons or study years? and 3) are anammox and incomplete denitrification $\left(\mathrm{N}_{2} \mathrm{O}\right.$ production) important in $\mathrm{N}$ removal during ice-cover 70 period? 


\section{MATERIALS AND METHODS}

\section{Study site}

74 The study was carried out in a constructed wetland (4 ha, with mean depth $1.0 \mathrm{~m}$ ), residence time ca.

7540 days (Figure 1) at Lammi WWTP of Hämeenlinnan Seudun Vesi Ltd, in southern Finland

$76\left(61^{\circ} 08^{\prime} 83^{\prime \prime} \mathrm{N}, 24^{\circ} 99^{\prime} 66^{\prime \prime} \mathrm{E}\right)$. The annual mean temperature of air is approximately $4-5^{\circ} \mathrm{C}$. Originally,

77 the wetland was constructed in 1963 to treat wastewaters from a dairy. Since the 1970s the wetland has

78 been used for tertiary treatment of municipal wastewaters from October to April. From May to

79 September, the treated wastewater has been discharged straight to the recipient Lake Ormajärvi, to

80 avoid aesthetic impairment resulting from high algae biomass discharged from the CW. During this

81 study, the treated wastewater was discharged into the study wetland all year round. The Lammi WWTP

82 is a small unit treating domestic wastewater of 4000 inhabitants, ca. $350000 \mathrm{~m}^{3} \mathrm{y}^{-1}$. Average daily

83 discharge (Q) to the WWTP is $871 \mathrm{~m}^{3} \mathrm{~d}^{-1}\left( \pm 335 \mathrm{~m}^{3} \mathrm{~d}^{-1}\right)$ varying seasonally. Highest discharge is

84 usually recorded during snow melt and in summer after heavy rains. The treatment process contains

85 sand separation, $\mathrm{P}$ removal by iron (II)-sulfate $\left(\mathrm{FeSO}_{4}\right)$ and nitrification of ammonium-nitrogen $\left(\mathrm{NH}_{4}{ }^{+}-\right.$

$86 \mathrm{~N})$ to $\mathrm{NO}_{3}{ }^{-}-\mathrm{N}$. After the treatment, wastewater is first directed to two small $\left(600 \mathrm{~m}^{2}\right.$ each $)$ settling

87 ponds with ca.12-hour residence time, then through a collection well gathering the waters before

88 entering the wetland. During summer, ca. $10-15 \%$ of the surface area is covered with vegetation

89 consisting mostly of Typha latifolia and Phragmites australis. 
90

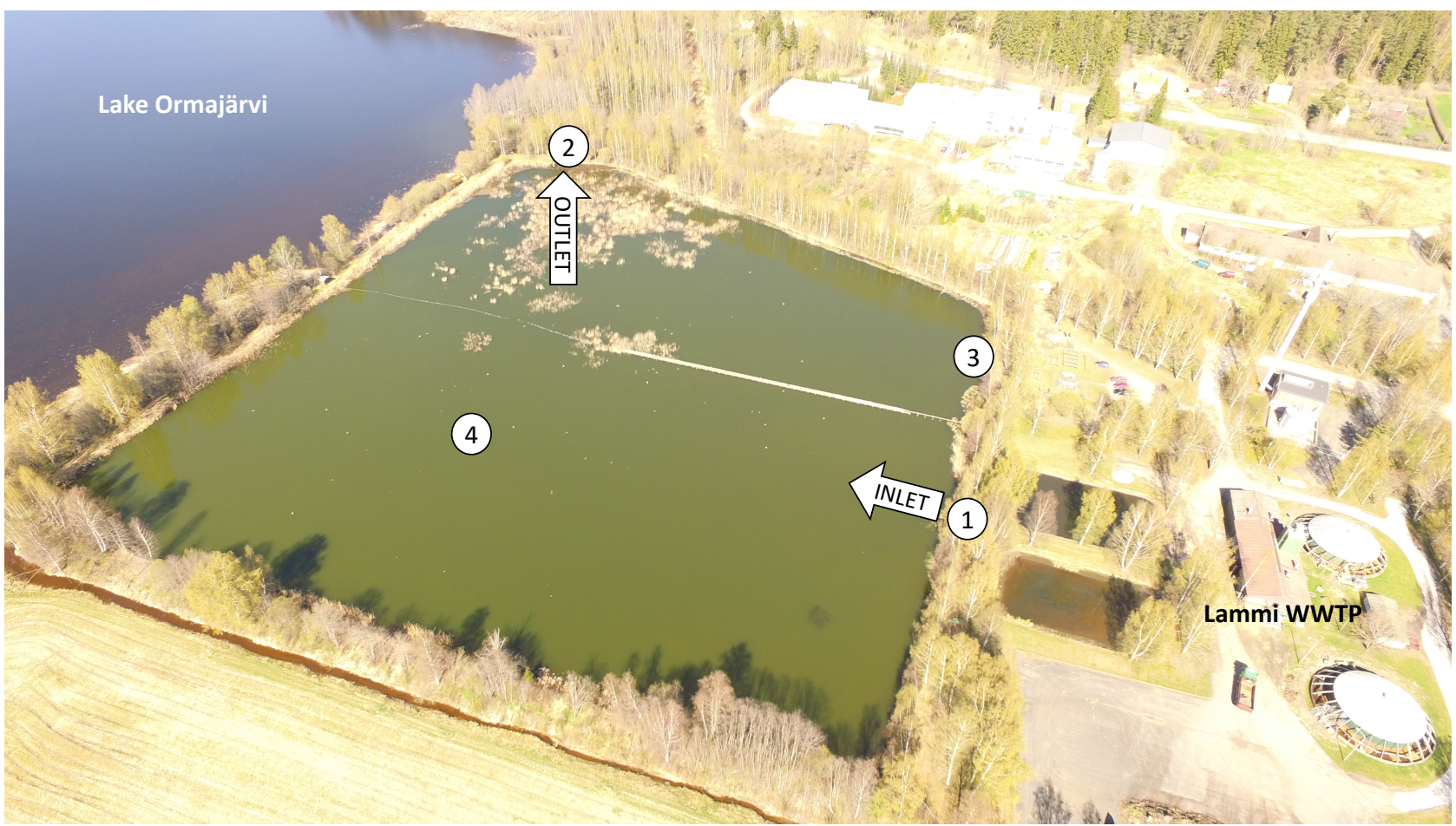

Figure 1. Constructed wetland of Lammi WWTP. Inlet is the place for treated wastewater discharge and outlet is the wetland discharge to Lake Ormajärvi. 1 = sampling of the WWTP discharge from a collection well, 2 = sampling of the wetland discharge, 3 = sediment sampling in the vegetated area in June and August 2015, $4=$ sediment sampling in the non-vegetated area in June and August 2015 as well as February 2017.

\section{Nutrient and chlorophyll- $a$ sampling and analyses}

Nutrient, dissolved organic carbon (DOC) and chlorophyll- $a(\mathrm{Chl})$ samples were taken biweekly during two years $(n=45)$, starting on 25 March 2015 continuing until 15 March 2017. Besides nutrients, we measured dissolved oxygen $\left(\mathrm{O}_{2}\right)$ and water temperature $(\mathrm{T})$ with an oxygen meter (ProODO, YSI) 0.1 $\mathrm{m}$ from the bottom and $0.1 \mathrm{~m}$ below the surface close to the inlet (depth ca. $1.0 \mathrm{~m}$ ) and $0.1 \mathrm{~m}$ below the surface close to the outlet (ca. $0.2 \mathrm{~m}$ ) (Figure 1). WWTP discharge nutrient samples and DOC were taken from the collection well (Figure 1). Wetland discharge nutrients, DOC and Chl were sampled 
104 from the outlet (Figure 1). All water samples were kept dark and cold $\left(+4{ }^{\circ} \mathrm{C}\right)$, and analyzed in the

105 laboratory within 1-3 hours. The samples were filtered through pre-rinsed (deionized water MQ; EMD

106 Millipore, Billerica) $0.45 \mu \mathrm{m}$ filters (Millex-HA, Merck Millipore). DOC was analyzed according to

107 SFS-EN 1484 (SFS-EN; same standard for Finland and Europe), with carbon analyzer (Ordior TOC-V,

108 Shimadzu). $\mathrm{NO}_{2}{ }^{-}-\mathrm{N}+\mathrm{NO}_{3}{ }^{-}-\mathrm{N}$ (henceforth referred to as $\mathrm{NO}_{\mathrm{x}}{ }^{-}-\mathrm{N}$ ) was analyzed following the SFS-EN

109 ISO 13395 standard. $\mathrm{NH}_{4}{ }^{+}-\mathrm{N}$ analysis was performed according to SFS-EN ISO 11732 standard with a

110 modification of using salicylate method. Total N (TN) was analyzed from a non-filtered sample

111 according to SFS-EN ISO 11905-1. Total P (TP) and $\mathrm{PO}_{4}{ }^{3-}-\mathrm{P}$ were analyzed following ISO/DIS 15681-

1122 standard, except persulphate digestion was used in total P analysis. All nutrient fractions were

113 measured with spectrophotometer (Gallery Plus, Thermo Scientific). Chl filters (Whatman GF/C glass-

114 fiber, Whatman) were stored in a freezer $-20{ }^{\circ} \mathrm{C}$ (SFS 5772) before spectrophotometrical analysis (UV-

115 1800, Shimadzu). Particulate N (PN) and particulate P (PP) were obtained by subtracting the

116 concentrations of dissolved fractions from totals (i.e. $\mathrm{PN}=\mathrm{TN}-\mathrm{NO}_{\mathrm{x}}{ }^{-} \mathrm{N}-\mathrm{NH}_{4}{ }^{+}-\mathrm{N}$ and $\mathrm{PP}=\mathrm{TP}-\mathrm{PO}_{4}{ }^{3-}$ -

117 P). Atmospheric $\mathrm{N}$ deposition to the wetland was estimated from data 2011-2016 provided by the

118 Finnish Meteorological Institute (FMI) from a monitoring site situated $\left(61^{\circ} 14.3926^{\prime} \mathrm{N}, 25^{\circ} 03.9161^{\prime} \mathrm{E}\right)$

119 ca. $6.5 \mathrm{~km} \mathrm{NE}$ from the WWTP wetland. As the $\mathrm{N}$ deposition for the whole wetland $\left(\mathrm{NO}_{\mathrm{x}}{ }^{-}-\mathrm{N}+\mathrm{NH}_{4}{ }^{+}-\right.$

$120 \mathrm{~N})$ was insignificant $\left(29 \mathrm{~g} \mathrm{~d}^{-1}\right)$ compared with the WWTP TN discharge $\left(23 \mathrm{~kg} \mathrm{~d}^{-1}\right)$, it was not taken

121 into account in mass balance.

122

123 Sediment analyses

124 After determining the water content of the sediment, porosity of the surface sediment $(0-3 \mathrm{~cm})$ was

125 calculated from a homogenized and dried $\left(105^{\circ} \mathrm{C}, 16-20 \mathrm{~h}\right)$ subsample. The content of organic carbon

126 was calculated from the loss on ignition (LOI\%) from oven-dried $\left(550^{\circ} \mathrm{C}, 2 \mathrm{~h}\right)$ surface sediment. 


\section{Denitrification and anammox measurements}

129 Before stable isotope incubations, the underlying assumptions of the ${ }^{15} \mathrm{~N}$-isotope pairing technique 130 (IPT) $)^{35}$ were verified with a concentration series of ${ }^{15} \mathrm{~N}$-labeled potassium nitrate $\left(\mathrm{K}^{15} \mathrm{NO}_{3,9} 98\right.$ atom\%,

131 Sigma-Aldrich) 3, 9, 18 and $30 \mathrm{mg} \mathrm{L}^{-1}$ using the wetland sediment.

133 Sediment $\mathrm{N}_{2}$-production rates were measured in June and August 2015 from a vegetated area as well as

134 from a non-vegetated area. Intact sediment cores (height $16 \mathrm{~cm}$, diameter $2.4 \mathrm{~cm}$ ) were collected by

135 hand from the vegetated area (Typha latifolia). In the non-vegetated area, larger sediment cores (height

$13634.1 \mathrm{~cm}$, diameter $4.1 \mathrm{~cm}$ ) were collected with a sediment sampler. Water-sediment ratio in the cores

137 were approximately $70 / 30 \%$. Samples were kept dark until delivered to the laboratory within an hour.

138 Denitrification rates for $\mathrm{N}_{2}$-production were obtained from cores incubated in the laboratory in dark at

139 in situ temperature. After addition of the label, the water column was gently mixed with a glass rod to

140 ensure homogenous distribution of the label, after which the cores were sealed with rubber stoppers and

141 incubated for $3 \mathrm{~h}$ with magnetic stirring (25 rpm). Assuming higher ambient $\mathrm{NO}_{\mathrm{x}}{ }^{-}$concentration in the

142 non-vegetated area (situated closer to the WWTP discharge) than in the vegetated area, we used

143 different concentrations of $\mathrm{K}^{15} \mathrm{NO}_{3}: 2.25,5.25,10.5$ and $15 \mathrm{mg} \mathrm{N} \mathrm{L}^{-1}$ in the vegetated area cores, and 6,

$14416.5,27$ and $37.5 \mathrm{mg} \mathrm{N} \mathrm{L}^{-1}$ in the cores from the non-vegetated area. For each concentration, we had 2-

1453 replicate cores. Two unlabeled cores from each site were used for measuring background $\mathrm{N}_{2}$

146 concentration. After incubation, the water and sediment of each core was stirred into slurry, and a 12

147 mL-subsample was taken from each core into a glass vial (Exetainer $12 \mathrm{~mL} 738 \mathrm{~W}$, Labco Limited)

148 containing $100 \mu \mathrm{L}$ of formaldehyde solution ( $37 \mathrm{wt} \%$, Sigma-Aldrich) to terminate all microbial

149 activity. Vials were stored upside down $\left(+4{ }^{\circ} \mathrm{C}\right.$, dark). Before stable isotope analysis, a helium

150 headspace $(5 \mathrm{~mL})$ was added to each $\mathrm{N}_{2}$ sample. ${ }^{36}$ 
152 In addition to summertime measurements, denitrification was measured in typically cold conditions

153 (avg air temp. $-7^{\circ} \mathrm{C}$ ) in the non-vegetated area during winter in February 2017. Unlike in summer, we

154 measured $\mathrm{N}_{2}$ as well as $\mathrm{N}_{2} \mathrm{O}$. Sampling procedure was the same as in June and August. However, we

155 used larger concentration series $(\mathrm{n}=12)$ of labeled ${ }^{15} \mathrm{NO}_{3}{ }^{-}-\mathrm{N}$ from 25.5 to $57.4 \mathrm{mg} \mathrm{N} \mathrm{L}^{-1}$. Again, two

156 unlabeled cores were used to determine the background $\mathrm{N}_{2}$ and $\mathrm{N}_{2} \mathrm{O}$ concentration. Due to cold

157 conditions, incubation time was increased to $5.5 \mathrm{~h}$ (in situ temperature $+3{ }^{\circ} \mathrm{C}$ ). For $\mathrm{N}_{2} \mathrm{O}$-production rate,

158 a slurry sample of $30 \mathrm{~mL}$ was collected into a polypropylene syringe $(60 \mathrm{~mL})$ avoiding any air bubbles

159 and $30 \mathrm{~mL}$ helium headspace was added in the syringes. After equilibration at $20^{\circ} \mathrm{C}$ by vigorous

160 shaking, $20 \mathrm{~mL}$ of the headspace was transferred to the pre-evacuated glass vial (12 $\mathrm{mL}$, Labco

161 Exetainer $\left.{ }^{\circledR}\right)$ and stored over-pressurised in the dark until analysis.

162

163 Isotope analysis and calculation of denitrification and anammox

164 Sample isotope mass areas $\left(\mathrm{m} / \mathrm{z} 28,29,30,44,45\right.$, and 46) as well as $\mathrm{N}_{2}$ and $\mathrm{N}_{2} \mathrm{O}$ concentrations were

165 analyzed with isotope ratio mass spectrometer (CF-IRMS, Isoprime Ltd) connected to a TraceGas

166 preconcentrator unit. For $\mathrm{N}_{2}$, a modified $\mathrm{N}_{2} \mathrm{O}$ method with no cryotrapping, and valves in $\mathrm{CO}_{2}$ mode

167 was used, while $\mathrm{N}_{2} \mathrm{O}$ analysis was done following the standard Isoprime TraceGas $\mathrm{N}_{2} \mathrm{O}$ procedure with

168 cryotapping. For summer samples, we measured only $\mathrm{N}_{2}$-production as previously reported. ${ }^{36}$ For

169 winter sampling, full and truncated denitrification $\left(\mathrm{N}_{2}+\mathrm{N}_{2} \mathrm{O}\right)$ and anammox rates were calculated with a

170 different procedure. ${ }^{37}$

\section{Wetland nutrient loading and retention}

172 Wastewater discharge $\left(\mathrm{Q}, \mathrm{m}^{-3} \mathrm{~d}^{-1}\right)$ entering the WWTP was used for wetland nutrient load calculations

173 assuming, that equal amount of water enters the wetland. We calculated wetland $\mathrm{N}$ and $\mathrm{P}$ retention for

174 the study years and for different periods (ice-free and ice-cover). From June to September, the 
175 decreasing effect of wetland surface evapotranspiration to the wetland discharge was taken into

176 account. ${ }^{38}$ Nutrient and DOC retention/release were calculated as the difference between load in and

177 load out relative to the incoming load.

178

179 Data analysis

180 We investigated the differences in nutrient retention between the study years, but also between ice-free

181 and ice-cover periods using non-parametric Wilcoxon signed rank tests. We used regression analysis to

182 investigate the relationships between environmental factors (temperature, $\mathrm{O}_{2}, \mathrm{pH}$ ) and Chl concentration.

183 In addition, the difference in nutrient concentration between wetland inlet and outlet relative to

184 environmental factors was examined to clarify the prevailing processes in the wetland. Finally, we

185 estimated yearly $\mathrm{N}$ removal in the wetland on the basis of the measured $\mathrm{N}$ removal process rates.

186 Softwares used were SPSS 24 and Microsoft Excel for Mac 16.12.

\section{RESULTS}

\section{Water temperature and oxygen conditions in the wetland}

189 Water temperature and dissolved oxygen concentration near the wetland outlet were highest from June 190 to August. Maximum temperature in the outflowing water was $20.3{ }^{\circ} \mathrm{C}$ during the first ice-free period 191 (2015) and $20.6{ }^{\circ} \mathrm{C}$ during the second, both measured in August. During ice-cover, temperature and $\mathrm{O}_{2}$

192 were similar in both study years, temperature being lowest in January. Lowest $\mathrm{O}_{2}$ saturation in the 193 wetland discharge was measured both years during ice-cover in February (2.8 and 8.0 \%). During ice-

194 free period, $\mathrm{O}_{2}$ saturation was higher in the first year reaching up to $270 \%$, while the maximum in the 195 second year was $230 \%$. 
198 WWTP discharge to the wetland was highest in spring (Table 1). Mean inflowing TN concentration

199 was $27.6 \mathrm{mg} \mathrm{N} \mathrm{L}^{-1}$. TN load from the WWTP to the wetland consisted mostly of $\mathrm{NO}_{\mathrm{x}}{ }^{-}-\mathrm{N}(67 \%)$, and 200 the proportion of $\mathrm{NH}_{4}{ }^{+}-\mathrm{N}$ was $28 \%$. During the study, $\mathrm{NO}_{\mathrm{x}}{ }^{-}-\mathrm{N}$ concentration of the incoming treated 201 wastewater varied from 1.5 to $51.0 \mathrm{mg} \mathrm{N} \mathrm{L}^{-1}$ being $19.6 \mathrm{mg} \mathrm{N} \mathrm{L}^{-1}$ on average. The proportions of 202 inorganic $\mathrm{N}$ fractions varied temporally (Figure 2), $\mathrm{NO}_{\mathrm{x}}{ }^{-}-\mathrm{N}$ loading from the WWTP being $0.9-57.8$, 203 and $\mathrm{NH}_{4}{ }^{+}-\mathrm{N}$ loading between $0.1-19.4 \mathrm{~kg} \mathrm{~N} \mathrm{~d}^{-1}$ (Table 1). $\mathrm{NH}_{4}{ }^{+}-\mathrm{N}$ loading was fourfold in the second 204 year ice-free period as compared with the one measured in the first year. Most of the TP-load from the 205 WWTP was in particulate form.

Table 1. WWTP discharge (Q, $\left.\mathrm{m}^{3} \mathrm{~d}^{-1}\right)$ and nutrient load $\left(\mathrm{kg} \mathrm{d}^{-1}\right)$ to the wetland from 2015 to 2017 (periodical averages within a study year, as well as mean, minimum, maximum and standard deviation for the whole study). Ice-free period April-November, ice-cover period December-March. DOC = dissolved organic carbon, $\mathrm{NH}_{4}{ }^{+}-\mathrm{N}$ $=$ ammonium-nitrogen, $\mathrm{PO}_{4}{ }^{3-}-\mathrm{P}=$ phosphate-phosphorus, $\mathrm{NO}_{\mathrm{x}}{ }^{-} \mathrm{N}=$ nitrate + nitrite-nitrogen, $\mathrm{TN}=$ total nitrogen, $\mathrm{TP}=$ total phosphorus, $\mathrm{PN}=$ particulate nitrogen, $\mathrm{PP}=$ particulate phosphorus.

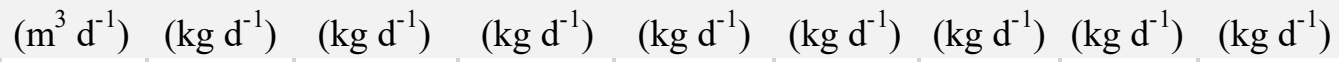

\section{1st year}

Ice-free period

Ice-cover period

885

2nd year

Ice-free period

1122

\begin{tabular}{|l|l}
\hline 8.4 & 2.2 \\
\hline 9.5 & 7.4 \\
\hline
\end{tabular}

Ice-cover period

78

\begin{tabular}{l|l}
\hline Mean & 871 \\
\hline
\end{tabular}

$$
\min
$$

$$
\max
$$

422

st.dev

1790

9.5

\begin{tabular}{l|l}
2.2 \\
7.4
\end{tabular}

\begin{tabular}{|c|c|c|c|c|c|}
\hline 0.10 & 20.1 & 23.3 & 0.30 & 1.00 & 0.20 \\
\hline 0.068 & 14.8 & 23.9 & 0.32 & 1.67 & 0.25 \\
\hline
\end{tabular}



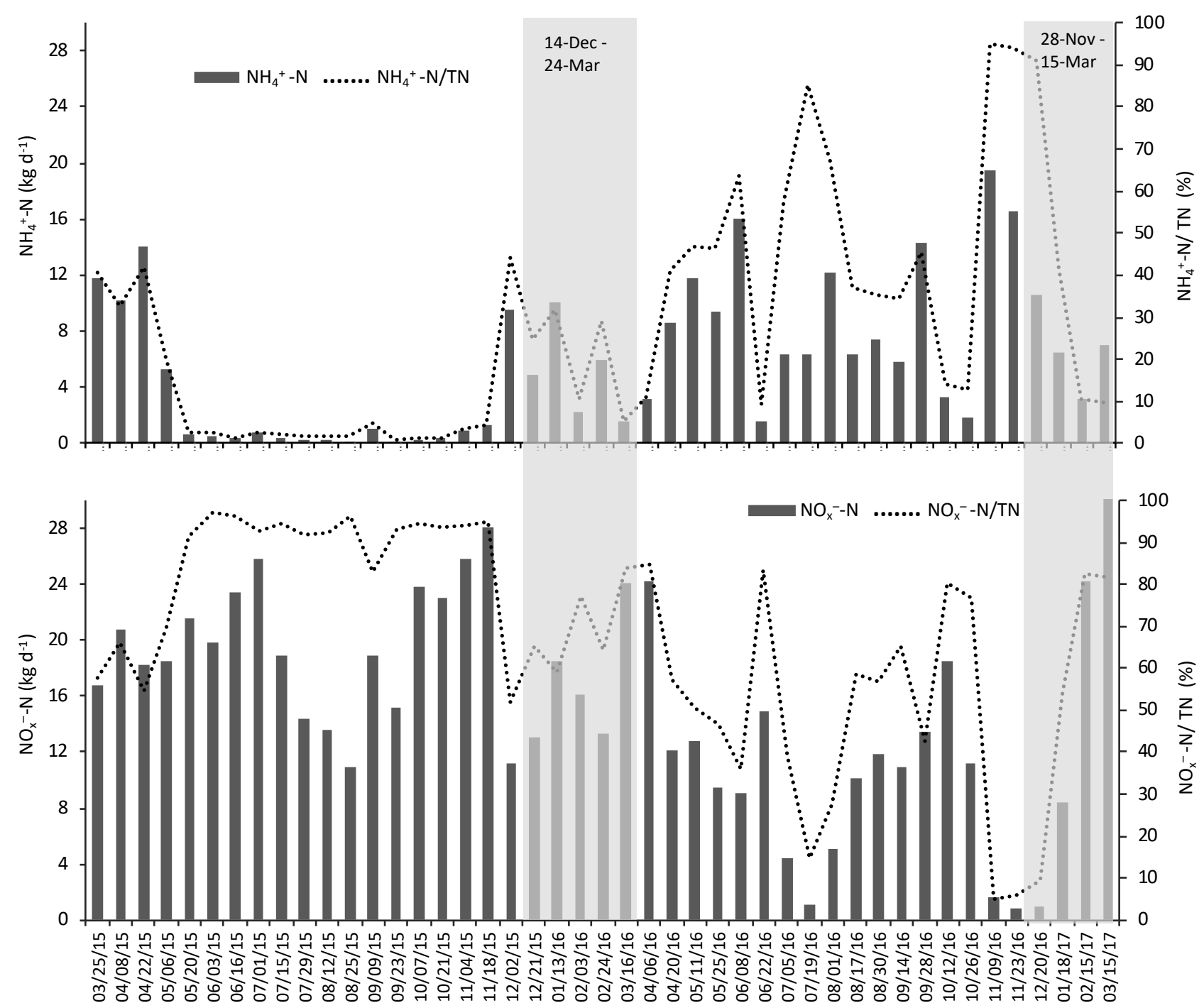

210 Figure 2. Daily ammonium-nitrogen $\left(\mathrm{NH}_{4}{ }^{+}-\mathrm{N}\right)$ and nitrite+nitrate-nitrogen $\left(\mathrm{NO}_{\mathrm{x}}{ }^{-}-\mathrm{N}\right) \mathrm{WWTP}$ discharge

211 (columns) to the wetland and the proportion (\%) of the inorganic $\mathrm{N}$ fractions from the total nitrogen

212 (TN) discharge (dotted line) between 2015 and 2017. Ice-cover periods are indicated with gray areas.

\section{Nutrient retention in the wetland}

215 During the two study years, the retention efficiency was positive for inorganic as well as for total 216 nutrient fractions (Table 2). More than half of the incoming $\mathrm{TN}, \mathrm{NH}_{4}{ }^{+}-\mathrm{N}, \mathrm{NO}_{\mathrm{x}}{ }^{-}-\mathrm{N}$ and $\mathrm{PO}_{4}{ }^{3-}-\mathrm{P}$ was 
217 retained, whereas the retention of TP was lower. Q and $\mathrm{N}$ retention had rather similar annual patterns, 218 whereas the retention of DOC, $\mathrm{PO}_{4}{ }^{3-}-\mathrm{P}$ and PP differed (Table 2). $\mathrm{N}$ retention varied also seasonally: 219 highest proportions of inorganic $\mathrm{N}$ fractions were retained during ice-free period, while the amount of 220 PN discharged from the wetland increased. Similarly, PP was produced during ice-free periods, but 221 retained during the ice-cover periods. The amount of particulate $\mathrm{N}$ and $\mathrm{P}$ increased with $\mathrm{Chl}\left(\mathrm{R}^{2}=0.83\right.$ 222 and 0.84 , respectively). Maximum Chl concentration $\left(1044 \mu \mathrm{g} \mathrm{L}^{-1}\right)$ was measured during the second 223 year, whereas during the first year the highest concentration was $525 \mu \mathrm{g} \mathrm{L}^{-1}$. Annual $\mathrm{N}$ retention in the 224 wetland was nearly $4300 \mathrm{~kg}$ for $\mathrm{TN}, 3600 \mathrm{~kg}$ for $\mathrm{NO}_{\mathrm{x}}{ }^{-}-\mathrm{N}$, nearly $1300 \mathrm{~kg}$ for $\mathrm{NH}_{4}{ }^{+}-\mathrm{N}_{\text {, meaning } 108,90}$ 225 and $33 \mathrm{~g} \mathrm{~N} \mathrm{~m}^{-2}$, respectively. PN release from the wetland to Lake Ormajärvi was $>500 \mathrm{~kg} \mathrm{~N} \mathrm{y}^{-1}$

226 (Table 2). The release of $\mathrm{NH}_{4}{ }^{+}-\mathrm{N}$ and $\mathrm{PO}_{4}{ }^{3-}-\mathrm{P}$ from the wetland to the lake during the second ice-cover 227 period can partly be explained with low $\mathrm{O}_{2}$ saturation $\left(\mathrm{R}^{2}=0.33\right.$, p-value $\left.<0.005\right)$.

Table 2. Mean nutrient retention (\%) and removed or released (-) average nutrient load $\left(\mathrm{kg} \mathrm{y}^{-1}\right)$ in the wetland. Ice-free period April-November, ice-cover period December-March. DOC $=$ dissolved organic carbon, $\mathrm{NH}_{4}{ }^{+}-\mathrm{N}=$ ammoniumnitrogen, $\mathrm{PO}_{4}{ }^{3-}-\mathrm{P}=$ phosphate-phosphorus, $\mathrm{NO}_{\mathrm{x}}{ }^{-}-\mathrm{N}=$ nitrite + nitrate-nitrogen, $\mathrm{TN}=$ total nitrogen, $\mathrm{TP}=$ total phosphorus, $\mathrm{PN}=$ particulate nitrogen, $\mathrm{PP}=$ particulate phosphorus. Results of the non-parametric Wilcoxon signed rank test with Zand P-values.

\begin{tabular}{|c|c|c|c|c|c|c|c|c|c|}
\hline & & DOC & $\mathrm{NH}_{4}^{+}-\mathrm{N}$ & $\mathrm{PO}_{4}{ }^{3-}-\mathrm{P}$ & $\mathrm{NO}_{\mathrm{x}}^{-}-\mathrm{N}$ & $\mathbf{T N}$ & $\mathbf{T P}$ & $\mathbf{P N}$ & $\mathbf{P P}$ \\
\hline \multicolumn{10}{|l|}{ 1st year $(n=23)$} \\
\hline \multicolumn{2}{|l|}{ Open water period (\%) } & -10.7 & 75.2 & 89.9 & 73.7 & 63.2 & 13.9 & -188.2 & -19.9 \\
\hline \multicolumn{2}{|l|}{ Ice-cover period $(\%)$} & -2.8 & 48.5 & 16.4 & 19.4 & 24.2 & 45.0 & -40.9 & 52.9 \\
\hline \multicolumn{10}{|l|}{ 2nd year $(n=22)$} \\
\hline \multicolumn{2}{|l|}{ Open water period (\%) } & 10.1 & 83.4 & 86.3 & 68.3 & 60.6 & 8.2 & -225.3 & -6.7 \\
\hline \multicolumn{2}{|l|}{ Ice-cover period $(\%)$} & 3.0 & -54.4 & -32.0 & 51.8 & 32.0 & 16.3 & 36.8 & 34.0 \\
\hline \multicolumn{2}{|l|}{ Avg change $\left(\mathrm{kg} \mathrm{y}^{-1}\right)$} & -114.2 & 1286.0 & 17.2 & 3580.5 & 4280.7 & 16.7 & -528.1 & -0.6 \\
\hline \multirow{2}{*}{$\begin{array}{l}\text { Difference between open water } \\
(n=34) \text { and ice-cover }(n=11) \text { periods }\end{array}$} & $\mathrm{Z}$ & -0.09 & -2.22 & -2.93 & -2.85 & -2.85 & -0.09 & -2.58 & -1.60 \\
\hline & $\mathrm{P}$ & 0.93 & 0.03 & 0.003 & 0.004 & 0.004 & 0.93 & 0.010 & 0.72 \\
\hline \multirow{2}{*}{ Difference between study years } & $\mathrm{Z}$ & -1.96 & -0.60 & -2.26 & -0.99 & -0.31 & -0.31 & -0.96 & -2.03 \\
\hline & $\mathrm{P}$ & 0.050 & 0.55 & 0.024 & 0.32 & 0.76 & 0.76 & 0.34 & 0.042 \\
\hline
\end{tabular}




\section{Denitrification and anammox rates}

231 Results from the ${ }^{15} \mathrm{NO}_{3}{ }^{-}$concentration series proved that denitrification (D14) based on the natural

$232{ }^{14} \mathrm{NO}_{3}{ }^{-}$was not affected by the added label ${ }^{15} \mathrm{NO}_{3}{ }^{-}(\mathrm{S} 1)$. In summer, the highest denitrification rate (252 $233 \mathrm{mg} \mathrm{N} \mathrm{m}^{-2} \mathrm{~d}^{-1}$ as $\mathrm{N}_{2}$ ) was found in June in the vegetated area (Figure 4a), when the bottom water 234 temperature was $15.5^{\circ} \mathrm{C}$. In the non-vegetated area, denitrification was fueled by both water column $235 \mathrm{NO}_{\mathrm{x}}{ }^{-}$and coupled nitrification-denitrification, whereas in the vegetated area, denitrification was 236 completely based on the water column $\mathrm{NO}_{\mathrm{x}}^{-}$. $\mathrm{NO}_{\mathrm{x}}^{-}-\mathrm{N}$ concentrations were 6.4 and $6.1 \mathrm{mg} \mathrm{N} \mathrm{L}^{-1}$ in 237 vegetated and non-vegetated area, respectively. In August (Figure 4b), the bottom water temperature 238 had increased to $18{ }^{\circ} \mathrm{C}$, but the $\mathrm{N}_{2}$-production rate was lower than in June, following $\mathrm{NO}_{\mathrm{x}}{ }^{-}-\mathrm{N}$ 239 concentration (non-vegetated area 3.4, vegetated area $2.4 \mathrm{mg} \mathrm{N} \mathrm{L}^{-1}$ ).

241 In winter (water temp. $+3^{\circ} \mathrm{C}$ ), $\mathrm{NO}_{\mathrm{x}}{ }^{-} \mathrm{N}$ concentration in the WWTP discharge reached the maximum 242 and the concentration above the sediment was nearly 10 -fold (24.9 $\left.\mathrm{mg} \mathrm{N} \mathrm{L}^{-1}\right)$ as compared with 243 August. $\mathrm{N}_{2}$-production rates were 94.7 for denitrification and $8.3 \mathrm{mg} \mathrm{N} \mathrm{m}^{-2} \mathrm{~d}^{-1}$ for anammox, 244 respectively. In addition, $44.0 \mathrm{mg} \mathrm{N} \mathrm{m}^{-2} \mathrm{~d}^{-1}$ was released as $\mathrm{N}_{2} \mathrm{O}$ from incomplete denitrification, so the 245 total $\mathrm{N}$ removal was $147.0 \mathrm{mg} \mathrm{N} \mathrm{m}^{-2} \mathrm{~d}^{-1}$ (Figure 4c). In average, complete denitrification contributed $24666 \%(45.5-75.1 \%)$, incomplete denitrification $\left(\mathrm{N}_{2} \mathrm{O}\right) 28.5 \%(20.4-46.2 \%)$, and anammox 5.5\% $(0.21-$ $24712.8 \%$ ) to the total $\mathrm{NO}_{\mathrm{x}}{ }^{-}-\mathrm{N}$ removal. 


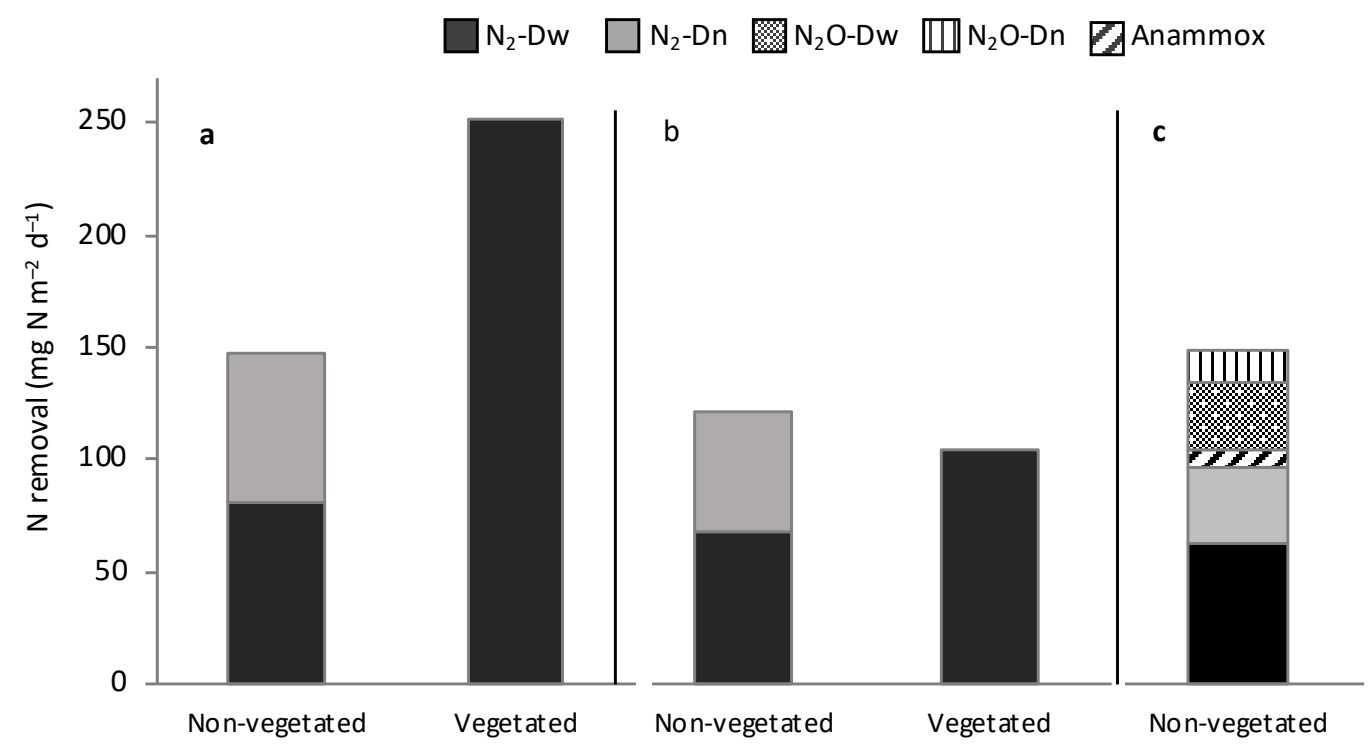

249 Figure 3. N removal rates by denitrification based on the original IPT in June (a), and in August (b). In 250 February (c), $\mathrm{N}$ removal rates by denitrification, incomplete denitrification $\left(\mathrm{N}_{2} \mathrm{O}\right)$ and anammox only in 251 the non-vegetated area. $D_{w}=$ denitrification based on water column nitrate, $D_{n}=$ denitrification based 252 on coupled nitrification-denitrification.

254 Based on the measured $\mathrm{N}_{2}$ production rates, and assuming: 1) the proportional $\mathrm{N}_{2} \mathrm{O}$ and anammox rates 255 relative to $\mathrm{N}_{2}$ being stable year round, 2) vegetation cover being $15 \%$ during ice-free period, the 256 calculated mean $\mathrm{N}$ removal was $8.5 \mathrm{~kg} \mathrm{~N} \mathrm{~d}^{-1}$ for the whole wetland, totaling in $1869 \mathrm{~kg} \mathrm{~N}$ during ice257 free period ( 8 months). During ice-cover period (4 months), the water temperature above the sediment 258 was ca. $12-15^{\circ} \mathrm{C}$ lower when compared with the summer measurements. Calculated $\mathrm{N}$ removal rate 259 was $5.9 \mathrm{~kg} \mathrm{~N} \mathrm{~d}^{-1}$, totaling $717 \mathrm{~kg} \mathrm{~N}$. To conclude, the 4-ha wetland removed $2586 \mathrm{~kg} \mathrm{~N} \mathrm{y}^{-1}$ through the 260 microbial gaseous $\mathrm{N}$-production (Figure4). This equals $72 \%$ of the $\mathrm{NO}^{-}-\mathrm{N}$ retention and $60 \%$ of the 261 TN retention per year calculated from mass balance. 


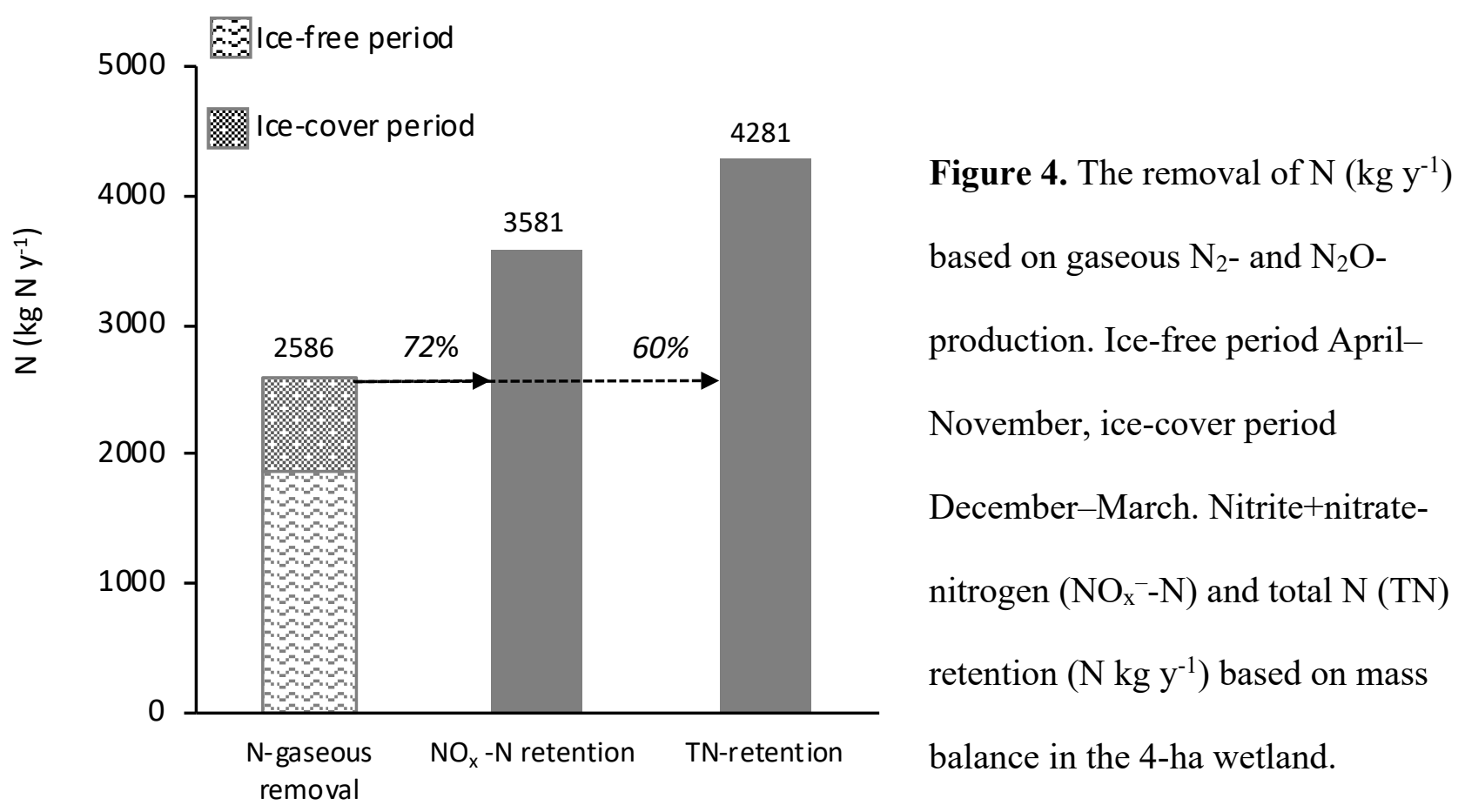

\section{DISCUSSION}

276 Here we demonstrated, that CWs can improve N removal also in northern WWTPs. Lammi WWTP 277 wetland had a TN retention of $52 \%$ with an average in-load of $207 \mathrm{~g} \mathrm{~m}^{-2}\left(27.6 \mathrm{mg} \mathrm{N} \mathrm{L}^{-1}\right)$. More than 278 half of the inorganic nutrients were retained, and the highest retention efficiency was measured for $\mathrm{N}$ : $27961-86 \%$ during ice-free period and 19-52\% during ice-cover period. Although the retention 280 efficiencies of inorganic nutrient fractions were lower during ice-cover periods, they were still mainly 281 positive. Only under poor oxygen conditions, ammonium-nitrogen and phosphate-phosphorus release 282 from the wetland was found. During the first ice-cover period, phosphate-phosphorus release was 283 found between January and March, when oxygen saturation in the wetland discharge was $2.8-30.1 \%$. 284 The second ice-cover period was similar and phosphate-phosphorus was released between late 285 November and February under oxygen saturation in the wetland discharge between 8 and $35 \%$. At 
286 present, Lammi WWTP has $\mathrm{N}$ reduction ca. 50\% without the CW, so it can easily achieve the $70 \% \mathrm{~N}$ 287 reduction target set by EU directive $(91 / 271 / \mathrm{ETY})^{39}$ and national regulation $(888 / 2006)^{40}$, although the 288 present environmental permission allows a lower $\mathrm{N}$ reduction due to local conditions in the recipient 289 lake. Our findings are in line with previous studies. Four treatment wetlands were studied in South 290 Sweden and TN removal varied between $700-1500 \mathrm{~kg} \mathrm{ha}^{-1} \mathrm{y}^{-1} \cdot{ }^{41} \mathrm{TN}$ retention was studied in 85 291 wetlands situated in variable climatic conditions with an average yearly in-load of $466 \mathrm{~g} \mathrm{~m}^{-2}(14.3 \mathrm{mg}$ $292 \mathrm{~N} \mathrm{~L}^{-1}$ ), and mean retention was $41 \% .^{42}$

294 Microbial processes, which are applied in wastewater technology, are sensitive to seasonal changes.

295 We found an increase in the ammonium-nitrogen load to the wetland from the WWTP, likely resulting 296 from a cold shock in bacterial community ${ }^{43}$, leading to an insufficient nitrification process at the start 297 of the ice-cover periods. Furthermore, we found high ammonium-nitrogen load from the WWTP 298 released to the wetland during the second ice-free period (shown in Fig. 2). This was caused by a 299 sudden significant increase in WWTP inflow coming from the wastewaters of a large Scout camp with 30017000 participants, which most likely disturbed the nitrification process in the WWTP. The WWTP 301 nitrification efficiency remained low until October, but ammonium was successfully nitrified in the 302 wetland. This indicates that northern treatment wetlands may not only improve the overall $\mathrm{N}$ retention efficiency under undisturbed situations, but can also buffer situations like disturbed WWTP nitrification process. Our results also show, that phosphate-phosphorus was mostly taken up by algae and bacteria during the ice-free periods. Wetland $\mathrm{N}$ removal was driven by denitrification. The results suggest that denitrifying bacteria were active also under ice in winter, agreeing with the few studies conducted in cold climate ${ }^{44,45}$. It seems denitrification rates are not controlled only by temperature, but also by nitrate availability ${ }^{27,44,46}$. In winter, ice-cover and snow can act as an insulator in shallow wetlands supporting microbiological processes in the sediment. ${ }^{47}$ The presence of anammox in the 
310 studied sediment was not shown as an increased denitrification rate along with the added label amount

311 in the ${ }^{15} \mathrm{NO}_{3}$ concentration series prior to the experiments. However, modest contribution of anammox 312 may still be present even if not $\operatorname{shown}^{48}$. Slow growing anammox bacteria may be suppressed by

313 fluctuations in environmental factors like oxygen, high nitrate and ammonium concentrations ${ }^{49-50}$, or by 314 low temperature $\left(<30^{\circ} \mathrm{C}\right)^{51}$. In addition, when organic $\mathrm{C}$ is not limiting, heterotrophic denitrification 315 bacteria generally out-compete anammox bacteria. ${ }^{49}$

317 Nitrous oxide production in aquatic systems can be promoted by different conditions, such as high $318 \mathrm{~N}^{30,52-53}$ and low availability of organic $\mathrm{C}^{55}$. However, the knowledge of nitrous oxide generation is 319 mostly limited to open water seasons. In our winter measurements, the contribution of nitrous oxide in 320 the total $\mathrm{N}$ removal was notable, which could be explained with organic $\mathrm{C}$ limiting the last 321 denitrification step ${ }^{54-55}$. Furthermore, low temperate has been found to affect more to nitrous oxide 322 reductase than enzymes producing nitrous oxide. ${ }^{30}$ Therefore, the portion of $\mathrm{N}_{2} \mathrm{O}$ from total 323 denitrification being stable all year round, may be an overestimation in the calculated $\mathrm{N}$ budget.

324 Denitrification in the vegetated area was entirely based on the nitrate diffusing from the water $\left(D_{w}\right)$, 325 even though earlier studies have reported plant roots to increase nitrification by oxygenation of the 326 sediment ${ }^{56}$. Typha latifolia might have been so efficient in its nutrient uptake from the sediment in June 327 and August that no ammonium was left available for nitrifiers. T. latifolia has been found to be well 328 adapted to grow in wetland soils where ammonium is the prevailing nitrogen compound. ${ }^{57}$ In general, 329 macrophytes have been reported to be beneficial in many ways to microbial $\mathrm{N}$ removal in CWs. ${ }^{24,42,58}$

330 Nitrous oxide rate from denitrification measured in February stands within the range from studies 331 performed in Norway, Sweden, Finland and Estonia reporting emissions in CWs treating wastewater: $332-5.3$ to $110 \mathrm{mg} \mathrm{N} \mathrm{m}^{-2} \mathrm{~d}^{-1} \cdot{ }^{59}$ In comparison with the winter $\mathrm{N}_{2}$ denitrification rates measured by similar 
333 technique in eutrophied Lake Ormajärvi (ca. $\left.2.7 \mathrm{mg} \mathrm{N} \mathrm{m}^{-2} \mathrm{~d}^{-1}\right)^{60}$, and in boreal agricultural stream 334 water $\left(1.7 \mathrm{mg} \mathrm{N} \mathrm{m}^{-2} \mathrm{~d}^{-1}\right)^{45}$, the measured $\mathrm{N}_{2}$ rate in the studied WWTP wetland was approximately 20335 fold most likely due to a higher nitrate availability. In addition to the measured high denitrification rate, 336 one of the key factors explaining efficient nutrient retention in the wetland is the relatively long 337 residence time among $\mathrm{CWs}^{61-62}$, although as compared with the average residence time in Finnish lakes 338 (ca. 2 years) ${ }^{63}$, it is very short. This highlights the efficiency of nutrient cycling in shallow wetlands.

339 In summary, constructed wetlands in northern latitudes have been largely ignored as a way to treat 340 wastewaters, mainly because their efficiency in cold climate is questioned. Lammi WWTP wetland 341 significantly reduces nutrient loading to Lake Ormajärvi. This study shows that microbial activity can 342 have an impressive impact on nitrogen removal despite low temperatures and cold winter if the water 343 residence time is sufficient. However, more information is needed about the relative nitrous oxide 344 production throughout a year, so that generation of this strong greenhouse gas can be mitigated.

\section{ACKNOWLEDGEMENTS}

347 This study was funded by Maj and Tor Nessling Foundation, Maa- ja vesitekniikan tuki ry, Lammin 348 biologisen aseman ympäristötutkimuksen säätiö and European Union project LIFE12 ENV/FI/597 N349 SINK, Ministry of the Environment project YM34/481/2017 as well as by Academy of Finland projects 350310302 for SLA and 286642 for AJR. The authors would like to thank Hämeenlinnan Seudun Vesi Ltd. 351 and the staff of Lammi Biological Station as well as prof. Heikki Setälä for his comments.

353 SUPPORTING INFORMATION

354 Figure $\mathrm{S} 1$. Results from the ${ }^{15} \mathrm{NO}_{3}{ }^{-}$concentration series experiment. 
355 Figure S2. Temperature and oxygen saturation in the wetland discharge from 25 March 2015 to 15 356 March 2017.

\section{REFERENCES}

(1) Sutton M.A.; Bleeker A.; Howard C.M.; Bekunda M.; Grizzetti B.; de Vries W.; van Grinsven H.J.M.; Abrol Y.P.; Adhya T.K.; Billen G.; Davidson E.A.; Datta A.; Diaz R.; Erisman J.W.; Liu X.J.; Oenema O.; Palm C.; Raghuram N.; Reis S.; Scholz R.W.; Sims T.; Westhoek H.; Zhang F.S. Our Nutrient World: The challenge to produce more food and energy with less pollution. Global Overview of Nutrient Management. Centre for Ecology and Hydrology, Edinburgh on behalf of the Global Partnership on Nutrient Management and the International Nitrogen Initiative. 2013.

(2) Carey R.O.; Migliaccio K.W. Contribution of Wastewater Treatment Plant Effluents to Nutrient Dynamics in Aquatic Systems: A Review. Environ. Manage. 2009, 44, 205-217.

(3) Tattari S.; Puustinen M.; Koskiaho J.; Röman E.; Riihimäki J. Vesistöjen ravinne- kuormituksen lähteet ja vähentämismahdollisuudet. Suomen Ympäristökeskuksen raportteja 2015, 35, 1-73. (In Finnish).

(4) Morris L.; Colombo V.; Hassell K.; Kellar C.; Leahy P.; Long S.M.; Myers J.H.; Pettigrove V. Municipal wastewater effluent licensing: A global perspective and recommendations for best practice. Review. Sci. Tot. Environ. 2017, 580, 1327-1339.

(5) Schindler D.W. Evolution of Phosphorus Limitation in Lakes. Science, New Series 1977, 195, (4275), 260-262.

(6) Schindler D.W.; Hecky R.E.; Findlay D.L.; Stainton M.P.; Parker B.R.; Paterson M.J.; Beaty K.G.; Lyng M.; Kasian S.E.M. Eutrophication of lakes cannot be controlled by reducing nitrogen input: results of a 37-year whole-ecosystem experiment. Proc. Natl. Acad. Sci. USA 2008, 105, 1125411258. 
379 (7) Elser J.J.; Bracken M.E.S.; Cleland E.E.; Gruner D.S.; Harpole W.S.; Hillebrand H.; Ngai J.T.;

380 Seabloom E.W.; Shurin J.B.; Smith J.E. Global analysis of nitrogen and phosphorus limitation of 381 primary producers in freshwater, marine and terrestrial ecosystems. Ecol. Lett. 2007, 10, 1135$382 \quad 1142$.

383 (8) Lewis W.M.; Wurtsbaugh W.A.; Paerl H.W. Rationale for control of anthropogenic nitrogen and 384 phosphorus to reduce eutrophication of inland waters. Environ. Sci. Technol. 2011, 45, 10300$385 \quad 10305$.

386 (9) Pietiläinen O.-P.; Räike A. Typpi ja fosfori Suomen sisävesien minimiravinteena. Suomen 387 ympäristö, 1999, 313, 1-64. (In Finnish).

388 (10) Paerl H.W. Controlling Eutrophication along the Freshwater-Marine Continuum: Dual Nutrient 389 (N and P) Reductions are Essential. Estuar. Coasts. 2009, 32, 593-601.

(11) Paerl H.W. It Takes Two to Tango: When and Where Dual Nutrient (N \& P) Reductions Are 391 Needed to Protect Lakes and Downstream Ecosystems. Environ. Sci. Technol. 2016, 50, 1080539210813.

393 (12) Bergström A.-K.; Blomkvist P.; Jansson M. Effects of atmospheric nitrogen deposition on 394 nutrient limitation and phytoplankton biomass in unproductive Swedish lakes. Limnol. Oceanogr. $395 \quad$ 2005, 50(3), 987-984.

396 (13) Heini A.; Puustinen I.; Tikka M.; Jokiniemi A.; Leppäranta M.; Arvola L. Strong dependence 397 between phytoplankton and water chemistry in a large temperate lake: spatial and temporal 398 perspective. Hydrobiologia 2014, 731, 139-150.

399 (14) Kolzau S.; Wiedner C.; Rücker J.; Köhler J.; Köhler A.; Dolman A.M. Seasonal Patterns of $400 \quad$ Nitrogen and Phosphorus Limitation in Four German Lakes and the Predictability of Limitation $401 \quad$ Status from Ambient Nutrient Concentrations. PLoS ONE 2014, 9(4), 1-14. 
402 (15) Funkey C.P.; Conley D.J.; Reuss N.S.; Humborg C.; Jilbert T.; Slomp C.P. Hypoxia sustains 403 cyanobacteria blooms in the Baltic Sea. Environ. Sci. Technol. 2014, 48, 2598-2602.

404 (16) Lepistö A.; Granlund K.; Kortelainen P.; Räike A. Nitrogen in river basins: Sources, retention in 405 the surface waters and peatlands, and fluxes to estuaries in Finland. Sci. Tot. Environ. 2006, 365 , $406 \quad 238-259$.

407 (17) Hautakangas, S.; Ollikainen, M.; Aarnos, K.; Rantanen, P. Nutrient abatement potential and 408 abatement costs of waste water treatment plants in the Baltic Sea region. Ambio 2014, 43(3), 352409360.

410 (18) Rankinen, K.; Huttunen, M.; Kinnunen, P. Efficiency for nitrogen abatement through modelling. 411 p. 4-5, In: Bergström, I.; Huotari, J., (eds.), EU Life+ N-SINK, Reduction of waste water nitrogen 412 load: demonstrations and modelling. 2017. Layman's report of project LIFE12 ENV/FI/597, 1-12. 413 (19) Lee C.; Fletcher T.D.; Sun G. Review. Nitrogen removal in constructed wetland systems. Eng. $414 \quad$ Life Sci. 2009, 9 (1), 11-22.

415 (20) Vymazal J. Constructed Wetlands for Wastewater Treatment: A Review. Water 2010, 2, 530$416 \quad 549$.

417 (21) Wu S.; Kuschk P.; Brix H.; Vymazal J.; Dong R. Development of constructed wetlands in 418 performance intensifications for wastewater treatment: A nitrogen and organic matter targeted 419 review. Water Res. 2014, 57, 40-55.

420 (22) Ghermandi A.; Bixio D; Thoeye C. The role of free water surface constructed wetlands as 421 polishing step in municipal wastewater reclamation and reuse. Sci. Tot. Environ. 2007, 380, 247$422 \quad 258$.

423 (23) Arheimer B.; Pers B.C. Lessons learned? Effects of nutrient reductions from constructing 424 wetlands in 1996-2006 across Sweden. Ecol. Eng. 2017, 103, 404-414. 
(24) Wang M.; Zhang D.; Dong J.; Tan S.K. Application of constructed wetlands for treating agricultural runoff and agro-industrial wastewater: a review. Hydrobiologia 2018, 805, 1-31.

(25) Mitsch W.J.; Gosselink J.G. Wetlands. $5^{\text {th }}$ ed. John Wiley \& Sons, Inc, USA, 2015.

(26) Dawson R.W.; Murphy K.L. The temperature dependency of biological denitrification. Water Res. 1972, 6, 71-83.

(27) Aalto S.L.; Saarenheimo J.; Ropponen J.; Juntunen J.; Rissanen A.J.; Tiirola M. Sediment diffusion method improves wastewater nitrogen removal in the receiving lake sediments. Water Res. 2018, 138, 312-322.

(28) Holmroos H.; Hietanen S.; Niemistö J.; Horppila J. Sediment resuspension and denitrification affect the nitrogen to phosphorus ratio of shallow lake waters. Fundam. Appl. Limnol. 2012, 180(3), $193-205$.

(29) Rissanen A.J.; Tiirola M.; Ojala A. Spatial and temporal variation in denitrification and in the denitrifier community in a boreal lake. Aquat. Microb. Ecol. 2011, 64, 27-40.

(30) Holtan-Hartwig L.; Dörsch P.; Bakken L.R. Low temperature control of soil denitrifying communities: kinetics of $\mathrm{N}_{2} \mathrm{O}$ production and reduction. Soil Biol. Biochem. 2002, 34, 1797-1806.

(31) Weymann D.; Geistlinger H.; Well R.; von der Heide C.; Flessa H. Kinetics of $\mathrm{N}_{2} \mathrm{O}$ production and reduction in a nitrate-contaminated aquifer inferred from laboratory incubation experiments. Biogeosciences 2010, 7, 1953-1972.

(32) Wrage N.; Velthof G.L.; van Beusichem M.L.; Oenema O. Role of nitrifier denitrification in the production of nitrous oxide. Soil Biol. Chem. 2001, 33, 1723-1732.

(33) Thamdrup B.; Dalsgaard T. Production of $\mathrm{N}_{2}$ through Anaerobic Ammonium Oxidation Coupled to Nitrate Reduction in Marine Sediments. Appl. Environ. Microbiol. 2002, 68(3), 1312-1318. 
447 (34) Jetten M.S.M.; van Niftrik L.; Strous M.; Kartal B.; Keltjens J.T.; Op den Camp H.J.M.

448 Biochemistry and molecular biology of anammox bacteria. Crit. Rev. Biochem Molec. Biol. 2009, $449 \quad 44(2-3), 65-84$.

450 (35) Hu Z.; Lotti T.; van Loosdrecht M.; Kartal B. Nitrogen removal with the anaerobic ammonium $451 \quad$ oxidation process. Biotechnol. Lett. 2013, 35, 1145-1154.

452 (36) Nielsen L.P. Denitrification in sediment determined from nitrogen isotope pairing. FEMS 453 Microb. Ecol. 1992, 86, 357-362.

454 (37) Hsu T.-C.; Kao S.-J. Technical Note: Simultaneous measurement of sedimentary $\mathrm{N}_{2}$ and $\mathrm{N}_{2} \mathrm{O}$ 455 production and a modified ${ }^{15} \mathrm{~N}$ isotope pairing technique. Biogeosciences 2013, 10, 7847-7862.

456 (38) Järvinen, J.; Kuusisto, E. Astiahaihdunta Suomessa 1961-1990. Vesi- ja ympäristöhallinnon 457 julkaisuja-sarja A, 1995, 1-220. (In Finnish).

458 (39) EU directive 91/271/EEC. http://data.europa.eu/eli/dir/1991/271/oj

459 (40) Finnish National Legislation (888/2006).

460 https://www.finlex.fi/en/laki/kaannokset/2006/en20060888.pdf

461 (41) Andersson J.L.; Kallner Bastviken S.; Tonderski K.S. Free water surface wetlands for wastewater 462 treatment in Sweden - nitrogen and phosphorus removal. Water Sci. Tech. 2005, 51(9), 39-46.

463 (42) Vymazal J. Removal of nutrients in various types of constructed wetlands. Sci. Tot. Environ. $464 \quad 2007,380,48-65$.

465 (43) Barria C.; Malecki M.; Arraiano C.M. Bacterial adaptation to cold. Review. Microbiology 2013, $466 \quad 159,2437-2443$.

467 (44) Cavaliere E.; Baulch H.M. Denitrification under lake ice. Biogeochemistry 2018, 137, $285-295$.

468 (45) Uusheimo S.; Tulonen T.; Aalto S.L.; Arvola L. Mitigating agricultural nitrogen load with 469 constructed ponds in northern latitudes: A field study on sedimental denitrification rates. Agric. $470 \quad$ Ecosyst. Environ. 2018, 261, 71-79. 
471 (46) McCrackin M.L.; Elser J.J. Atmospheric nitrogen deposition influences denitrification and 472 nitrous oxide production in lakes. Ecology 2010, 91(2), 528-539.

473 (47) Wittgren H.B.; Mæhlum T. Wastewater treatment wetlands in cold climate. Water Sci. Tech. $474 \quad 1997,35(5), 45-53$.

475 (48) Trimmer M.; Risgaard-Petersen N.; Nicholls J.C.; Engströn P. Direct measurement of anaerobic 476 ammonium oxidation (anammox) and denitrification in intact sediment cores. Mar. Ecol. Prog. Ser. $477 \quad 2006,326,37-47$.

478 (49) Jin R.-C.; Yang G.-F.; Yu J.-J.; Zheng P. The inhibition of the Anammox process: A review. 479 Chem. Eng. J. 2012, 197, 67-79.

480 (50) Terada A.; Zhou C.; Hosomi M. Presence and detection of anaerobic ammonium-oxidizing 481 (anammox) bacteria and appraisal of anammox process for high-strength nitrogenous wastewater 482 treatment: a review. Clean Tech. Environ. Policy. 2011, 13, 759-781.

483 (51) Tomaszewski M.; Cema G.; Ziembińska-Buczyńska A. Influence of temperature and pH on the 484 anammox process: A review and meta-analysis. Chemosphere 2017, 182, 203-214.

485 (52) Saarenheimo J.; Rissanen A.J.; Arvola L.; Nykänen H.; Lehmann M.F.; Tiirola M. Genetic and 486 Environmental Controls on Nitrous Oxide Accumulation in Lakes. PLoS ONE 2015, 10(3), $487 \quad e 0121201,1-14$

488 (53) Hefting M.M.; Bobbink R.; de Caluwe H. Nitrous Oxide Emission and Denitrification in 489 Chronically Nitrate-Loaded Riparian Buffer Zones. J. Environ. Qual. 2003, 32, 1194-1203. 490 (54) Tiedje J.M. Ecology of denitrification and dissimilatory of nitrate reduction to ammonium. In: 491 Zender A.J.B. (ed.), Environmental microbiology of anaerobes. John Wiley \& Sons Inc. N.Y., 4921988.

493 (55) Songliu L.U.; Hongying H.; Yingxue S.; Jia Y. Effect of carbon source on the denitrification in 494 constructed wetlands. J. Environ. Sci. 2009, 21, 1036-1043. 
495 (56) Reddy K.R.; Patrick W.H.; Lindau C.W. Nitrification-denitrification at the plant root-sediment 496 interface in wetlands. Limnol. Oceanogr. 1989, 34(6), 1004-1013.

497 (57) Brix H., Dyhr-Jensen K., Lorenzen B. Root-zone acidity and nitrogen source affects Typha 498 latifolia L. growth and uptake kinetics of ammonium and nitrate. J. Experiment. Botany, 2002, $499 \quad$ 53(379), 2441-2450.

500 (58) Kallner Bastviken S.; Weisner S.E.B.; Thiere G.; Svensson J.M.; Ehde P.M.; Tonderski K.S. 501 Effects of vegetation and hydraulic load on seasonal nitrate removal in treatment wetlands. Ecol. $502 \quad$ Eng. 2009, 35, 946-952.

503 (59) Søvik A.K.; Kløve B. Emission of $\mathrm{N}_{2} \mathrm{O}$ and $\mathrm{CH}_{4}$ from a constructed wetland in southeastern $504 \quad$ Norway. Sci. Tot. Environ. 2007, 380, 28-37.

505 (60) Rissanen A.J.; Tiirola M.; Hietanen S; Ojala A. Interlake variation and environmental controls of 506 denitrification across different geographical scales. Aquat. Microb. Ecol. 2013, 69, 1-16.

507 (61) Arheimer, B.; Wittgren, H.B. Modelling N retention in potential wetlands at the catchment scale. $508 \quad$ Ecol. Eng. 2002, 19 (1), 63-80.

509 (62) Toet S.; Van Logtestijn R.S.P.; Kampf R.; Schreijer M.; Verhoeven J.T.A. The effect of 510 hydraulic retention time on the removal of pollutants from sewage treatment plant effluent in a 511 surface-flow wetland system. Wetlands 2005, 25(2), 375-391.

512 (63) Niemi J.; Lepistö L.; Mannio J.; Mitikka S.; Pietiläinen O.-P. Quality and trends of inland waters. 513 In: Inland and Coastal Waters of Finland; Eloranta P. University of Helsinki, Saarijärvi, 2004. 